\title{
IMPLEMENTASI KEBIJAKAN ALOKASI DANA GAMPONG (ADG) DALAM MENINGKATKAN PEMBANGUNAN DI KAB. ACEH BARAT
}

\author{
Aduwina Pakeh \\ Fakultas Ilmu Sosial dan Ilmu Politik,Universitas Teuku Umar \\ email: eaduwina@utu.ac.id
}

\begin{abstract}
Law No. 06 of 2014 on the village said that the source of income of the village consists of a). Revenue native village consisting of; results of operations of the village, the wealth of the village, the result of self-help and participation, the results of gotong royong, and other legitimate revenue villages; $b$ ). Tax-sharing districts / cities of at least $10 \%$ of the levy for the village and district / city mostly reserved for the village; $c$ ). Part of the financial balance of central and local received by the district I city to the village at least $10 \%$ which distribution proportionally to each village which is the Village Fund Allocation; d). Financial assistance from the government, provincial government, regency / municipal government in the implementation of government affairs; e). grants and donations from third parties that are not binding. The purpose of this study is to describe and analyze the implementation of Government policy on the Village Fund Budget (ADD) -The Village Fund Allocation (ADG - Government of Aceh) in the Village Pante Ceureumen West Aceh District. Based on the results, it can be concluded that development plan is not yet fully meet aspirations of society with mutual trust and open.The activities conducted in the public aspirations village level so that only representatives of the community is able to convey the problems and needs facing. Only a small portion is in the village of Pante Ceureumen who have to meet the aspirations of the mutual trust and open.
\end{abstract}

Keywords: Implementation, Policy, The Village Fund Allocation (ADG), the Village, Pante Ceureumen

\section{PENDAHULUAN}

Kelahiran UU No. 6 tahun 2014 tentang Desamemberikan kepastian hukum terhadap perimbangan keuangan desa dan kabupaten/kota. Desa (Gampong-Pemerintah Aceh) memperoleh jatah Alokasi Dana Desa (ADD) - Alokasi Dana Gampong (ADG-Pemerintah Aceh). ADG yang diberikan ke gampong merupakan hak gampong. Sebelumnya, gampong tidak memperoleh kejelasan 
anggaran untuk mengelola pembangunan, pemerintahan dan kemasyarakatan gampong. Saat ini, melalui ADG berpeluang untuk mengelola pembangunan, pemerintahan dan sosial kemasyarakatan gampong secara otonom. ADG adalah dana yang diberikan kepada gampong yang berasal dari dana perimbangan keuangan pemerintah pusat dan daerah yang diterima oleh kabupaten/kota. Disejumlah daerah kabupaten/kota, sebutan untuk ADD menggunakan istilah yang berbeda. Hal ini dimungkinkan, mengingat keanekaragaman bahasa dan adat istiadat di Indonesia.

ADG merupakan hak gampong sebagaimana pemerintah daerah kabupaten/kota memiliki hak untuk memperoleh anggaran DAU (Dana Alokasi Umum) dan DAK (Dana Alokasi Khusus) dari Pemerintah Pusat. Dapat dianalogikan bahwa ADG merupakan DAU/DAK bagi gampong, dan bagi sebagian banyak gampong, ADG adalah sumber pembiayaan utama karena memang terbatasnya PAG. Untuk itu diharapkan aparatur gampong, utamanya Keuchik (Kepala Desa) lebih memposisikan ADG sebagai stimulan bagi pemberdayaan masyarakat dan bukan hanya pada pembangunan prasarana fisik yang bermanfaat jangka pendek / kecil kontribusinya bagi pemberdayaan masyarakat atau lebih lebih sebagai sumber penghasilan bagi aparatur desa. Kurang terarahnya distribusi ADG selama ini dapat dilihat dari realita bahwa sebagian besar gampong mengalokasikan anggaran ADG-nya untuk perbaikan / peningkatan fisik jalan, gedung, irigasi yang kontribusinya rendah dalam mendorong pemberdayaan masyarakat dan sangat sedikit gampong yang mengarahkan anggaran ADG-nya bagi pembiayaan yang lebih produktif semisal pembentukan BUMG, Bank Gampong, Pasar Gampong, pinjaman modal secara bergulir tanpa bunga untuk kegiatan pengembangan UKM/RT diwilayahnya, pengembangan produk unggulan gampong, ataupun kegiatan produktif lainnya.

Tujuan ADG itu sendiri adalah: (1). Untuk memperkuat kemampuan keuangan desa (APBDes) - (APBG-Pemerintah Aceh), dengan demikian sumber APBG terdiri dari Pendapatan Asli Gampong (PAG) ditambah ADG. (2). Untuk unsur keleluasaan bagi gampong dalam mengelola persoalan pemerintahan, pembangunan serta unsur kemasyarakatan. (3). Untuk mendorong terciptanya demokrasi gampong. (4). Untuk meningkatkan pendapatan dan pemerataannya dalam rangka mencapai kesejahteraan masyarakat gampong.

Beberapa Manfaat ADG Bagi Kabupaten/Kota yakni: pertama Kabupaten/Kota dapat menghemat tenaga untuk membiarkan desa mengelola otonominya, tanpa terus bergantung kepada Kabupaten/Kota. Kedua Kabupaten/kota bisa lebih berkonsentrasi meneruskan pembangunan pelayanan unsur untuk skala luas yang jauh lebih strategis dan lebih bermanfaat untuk jangka panjang. Pengelolaan ADG harus menyatu di dalam pengelolaan APBG, sehingga prinsip pengelolaan ADGsama persis dengan pengelolaan APBG, yang harus mengikuti prinsip-prinsip good governance yakni partisipatif, transparan, akuntabel, kesetaraan.

Persoalan sekarang yang dialami dalam perencanaan pembangunan gampong khususnya dalam penyusunan Alokasi Dana Gampong di Gampong Pante Ceureumen yakni masalah seputar keterlibatan masyarakat, peran pemerintah gampong, peran Tuha Peut. Bagaimana kebijakan ADG dalam implementasinya untuk mensejahterakan masyarakat gampong. Didalamnya apakah ADG memberi ruang lebih luas kepada akses dan aspirasi masyarakat untuk melibatkan diri dalam pembangunan. Pada kenyataannya partisipasi masyarakat sangat lemah, terkadang penyusunan ADG dilakukan secara sepihak oleh pemerintah desa, ataupun kalau melibatkan masyarakat hanya sekedar formalitas saja untuk memenuhi peraturan yang ada. Hasilnya nanti, pembangunan yang direalisasikan menimbulkan masalah baru karena tidak mengakomodasi dan melibatkan masyarakat secara baik. Persoalan lain lagi dalam hal penggunaandana ADG tersebut yang tidak transparan ataupun penggunaannya tidak seperti yang diharapkan untuk pembangunan kesejahteran masyarakat

\section{Konsep Implementasi}

Menurut Kamus Besar Bahasa Indonesia (KBBI), implementasi adalah pelaksanaan, penerapan. Sedangkan menurut Susilo (2007) implementasi merupakan suatu penerapan idea, konsep, kebijakan, atau inovasi dalam suatu tindakan praktis sehingga memberikan dampak, baik barupa perubahan pengetahuan, keterampilan maupun nilai, dan sikap. Dalam Oxford Advance Learner Dictionary dikemukakan bahwa implementasi adalah "put something into effect" (penerapan sesuatu yang memberikan efek atau dampak).

Secara etimologis pengertian implementasi menurut Kamus Webster yang dikutip oleh Solichin Abdul Wahab adalah: "Konsep implementasi berasal dari bahasa inggris yaitu to implement. Dalam kamus besar Webster, to implement (mengimplementasikan) berati to provide the means for 
carrying out (menyediakan sarana untuk melaksanakan sesuatu); dan to give practical effect to (untuk menimbulkan dampak/akibat terhadap sesuatu)"(Webster dalam Wahab, 2001).

Menurut Usman (2002) implementasi bermuara pada aktivitas, aksi, tindakan, atau adanya mekanisme suatu sistem. Implementasi bukan sekedar aktivitas, tetapi suatu kegiatan yang terencana dan untuk mencapai tujuan kegiatan. Implementasi bukan sekedar aktivitas, tetapi suatu kegiatan yang terencana dan dilakukan secara sungguh-sungguh berdasarkan acuan norma tertentu untuk mencapai tujuan kegiatan. Oleh karena itu implementasi tidak berdiri sendiri tetapi dipengaruhi oleh objek berikutnya.

Implementasi juga diartikan sebagai perluasan aktivitas yang saling menyesuaikan proses interaksi antara tujuan dan tindakan untuk mencapainya serta memerlukan jaringan pelaksana, birokrasi yang efektif (Setiawan, 2004). Implementasi yaitu merupakan proses untuk melaksanakan ide, proses atau seperangkat aktivitas baru dengan harapan orang lain dapat menerima dan melakukan penyesuaian dalam tubuh birokrasi demi terciptanya suatu tujuan yang bisa tercapai dengan jaringan pelaksana yang bisa dipercaya.

Syukur dalam Surmayadi (2005) mengemukakan ada tiga unsur penting dalam proses implementasi yaitu: (1) adanya program atau kebijakan yang dilaksanakan (2) target group yaitu kelompok masyarakat yang menjadi sasaran dan ditetapkan akan menerima manfaat dari program, perubahan atau peningkatan (3) unsur pelaksana (Implementor) baik organisasi atau perorangan untuk bertanggung jawab dalam memperoleh pelaksanaan dan pengawasan dari proses implementasi tersebut.

Implementasi melibatkan usaha dari policy makers untuk memengaruhi apa yang oleh Lipsky disebut "street level bureaucrats" untuk memberikan pelayanan atau mengatur prilaku kelompok sasaran (target group). Untuk kebijakan yang sederhana, implementasi hanya melibatkan satu badan yang berfungsi sebagai implementor, misalnya, kebijakan pembangunan infrastruktur publik untuk membantu masyarakat agar memiliki kehidupan yang lebih baik, sebaliknya untuk kebijakan makro, misalnya, kebijakan pengurangan kemiskinan di pedesaan, maka usaha-usaha implementasi akan melibatkan berbagai institusi, seperti birokrasi kabupaten, kecamatan, pemerintah desa.

Menurut uraian di atas, implementasi itu merupakan tindakan-tindakan yang dilakukan oleh pemerintah untuk mencapaitujuan yang telah di tetapkan dalam suatu keputusan kebijakan

\section{Kebijakan}

Kebijakan (policy) merupakan suatu program kegiatan yang dipilih atau diputuskan oleh seseorang atau kelompok orang dan dapat dilaksanakan serta berpengaruh terhadap sejumlah orang dalam rangka mencapai tujuan tertetu. Sementara itu kata publik merupakan kata untuk menjelaskan kebijakan yang dimaksud dapat dibedakan dari kebijakan/keputusan perorangan atau kelompok (Islamy, 2007).

Adapun menurut Woll kebijakan merupakan aktivitas pemerintah untuk memecahkan masalah di masyarakat baik secara langsung maupun melalui berbagai lembaga yang mempengaruhi kehidupan masyarakat (dalam Tangkilisan, 2003). Dari kedua definisi di atas dapat disimpulkan bahwa kebijakan merupakan tindakan-tindakan atau keputusan yang dibuat oleh pemerintah, dimana tindakan atau keputusan dimaksud memiliki pengaruh terhadap masyarakatnya.

Kebijakan diciptakan untuk mengatur kehidupan masyarakat untuk mencapai tujuan yang telah disepakati bersama. Menurut Fredrickson dan Hart kebijakan adalah suatu tindakan yang mengarah pada tujuan yang diusulkan oleh seseorang, kelompok atau pemerintah dalam lingkungan tertentu sehubungan dengan adanya hambatan-hambatan tertentu sambil mencari peluang-peluang untuk mencapai tujuan / mewujudkan sasaran yang diinginkan (dalam Tangkilisan, 2003).

Kebijakan sebenarnya telah sering kita dengar dalam kehidupan sehari-hari, istilah kebijakan seringkali disamakan dengan istilah kebijaksanaan. Jika diuraikan terdapat perbedaan antara kebijakan dengan kebijaksanaan. Adapun pengertian kebijaksanaan lebih ditekankan kepada pertimbangan dan kearifan seseorang yang berkaitan dengan dengan aturan-aturan yang ada. Sedangkan kebijakan mencakup seluruh bagian aturan-aturan yang ada termasuk konteks politik, karena pada dasarnya proses pembuatan kebijakan sesungguhnya merupakan suatu proses politik. Menurut M. Irafan Islamy berpendapat bahwa kebijaksanaan memerlukan pertimbangan-pertimbangan yang lebih jauh lagi (lebih menekankan kepada kearifan seseorang), sedangkan kebijakan mencakup aturan-aturan yang 
ada di dalamnya sehingga policy lebih tepat diartikan sebagai kebijakan, sedangkan kebijaksanaan merupakan pengertian dari kata wisdom (Islamy, 1997).

\section{Definisi Implementasi Kebijakan}

Pemahaman umum mengenai implementasi kebijakan dapat diperoleh dari pernyataan bahwa implementasi merupakan proses umum tindakan administratif yang dapat diteliti pada tingkat program tertentu. Proses implementasi baru akan dimulai apabila tujuan dan sasaran telah ditetapkan, program kegiatan telah tersusun dan dana telah siap dan disalurkan untuk mencapai sasaran. Jika pemahaman ini diarahkan pada lokus dan fokus (perubahan) dimana kebijakan diterapkan akan sejalan dengan pandangan Van Meter dan van Horn yang dikutip oleh Parsons (1995) dan Wibawa, dkk., (1994) bahwa implementasi kebijakan merupakan tindakan yang dilakukan oleh (organisasi) pemerintah dan swasta baik secara individu maupun secara kelompok yang dimaksudkan untuk mencapai tujuan.

Implementasi kebijakan menghubungkan antara tujuan kebijakan dan realisasinya dengan hasil kegiatan pemerintah. Ini sesuai dengan pandangan Van Meter dan van Horn (Grindle, 1980) bahwa tugas implementasi adalah membangun jaringan yang memungkinkan tujuan kebijakan publik direalisasikan melalui aktivitas instansi pemerintah yang melibatkan berbagai pihak yang berkepentingan.

Alasan mengapa implementasi kebijakan diperlukan mengacu pada pandangan para pakar bahwa setiap kebijakan yang telah dibuat harus diimplementasikan. Oleh karena itu, implementasi kebijakan diperlukan karena berbagai alasan atau perspektif. Berdasarkan perspektif masalah kebijakan, sebagaimana yang diperkenalkan oleh Edwards III (1984), implementasi kebijakan diperlukan karena adanya masalah kebijakan yang perlu diatasi dan dipecahkan. Edwards III memperkenalkan pendekatan masalah implementasi dengan mempertanyakan faktor-faktor apa yang mendukung dan menghambat keberhasilan implementasi kebijakan. Berdasarkan pertanyaan retoris tersebut dirumuskan empat faktor sebagai sumber masalah sekaligus prakondisi bagi keberhasilan proses implementasi, yakni komunikasi, sumber daya, sikap birokrasi atau pelaksana, dan struktur organisasi termasuk tata aliran kerja birokrasi. Empat faktor tersebut merupakan kriteria yang perlu ada dalam implementasi suatu kebijakan.

Implementasi kebijakan di-perlukan untuk melihat kepatuhan kelompok sasaran kebijakan. Oleh karena itu, dilihat dari perspektif perilaku, kepatuhan kelompok sasaran merupakan faktor penting yang menentukan keberhasilan implementasi kebijakan. Pemahaman ini sejalan dengan pandangan Ripley dan Franklin (1986) bahwa untuk mendukung keberhasilan implementasi kebijakan perlu didasarkan pada tiga aspek, yaitu: (1) tingkat kepatuhan birokrasi terhadap birokrasi di atasnya atau tingkatan birokrasi, sebagaimana diatur dalam undang-undang, (2) adanya kelancaran rutinitas dan tidak adanya masalah; serta (3) pelaksanaan dan dampak (manfaat) yang dikehendaki dari semua program terarah.

\section{Teori Implementasi Kebijakan}

Dalam pandangan Edwards III (1984), implementasi kebijakan dipengaruhi oleh empat variabel, yakni: (1) komunikasi, (2) sumberdaya, (3) disposisi, dan (4) struktur birokrasi. Keempat variabel tersebut juga saling berhubungan satu sama lain. Menurut meter dan horn, ada lima variable yang memengaruhi kinerja implementasi iaitu: standar dan sasaran kebijakan; sumber daya; hubungan antar organisasi; karakteristik agen pelaksan; serta kondisi sosial, politik, dan ekonomi.

Dalam pandangan Weimer dan Vining (1999) ada tiga kelompok variabel besar yang dapat memengaruhi keberhasilan implementasi suatu program, yakni: logika kebijakan, lingkungan tempat kebijakan dioperasikan, dan kemampuan implementor kebijakan.

a. Logika dari suatu kebijakan. Ini dimaksudkan agar suatu kebijakan yang ditetapkan masuk akal dan mendapat dukungan teoritis.

b. Lingkungan tempat kebijakan tersebut dioperasikan akan memengaruhi keberhasilan impelmentasi suatu kebijakan. Yang dimaksud lingkungan ini mencakup lingkungan sosial, politik, ekonomi,hankam, dan fisik atau geografis.

c. Kemampuan implementor. Keberhasilan suatu kebijakan dapat dipengaruhi oleh tingkat kompetensi dan keterampilan dari implementor kebijakan.

\section{Konsep Alokasi Dana Desa (ADD) - Alokasi Dana Gampong (ADG)}


Alokasi Dana Desa(ADD) adalah bagian keuangan Desa yang diperoleh dari Bagi Hasil Pajak Daerah dan Bagian dari Dana Perimbangan Keuangan Pusat dan Daerah yang diterima oleh kabupaten. Menurut Undang-Undang No 06 Tahun 20144 Tentang Desa pada Fasal 72 Ayat (1.d) dan (4) menyebutkan bahwa Alokasi Dana Desa merupakan bagian dari dana perimbangan yang diterima oleh Kabupaten/Kota paling sedikit 10\% (sepuluh perseratus) berasal dari APBD Kabupaten/Kota setelah dikurangi Dana Alokasi Khusus (DAK).

Selanjutnya masih dalam UU yang sama pada Pasal 79, mengamanatkan pemerintah desa harus menyusun perencanaan pembangunan desa sesuai dengan kewenangannya dengan mengacu pada perencanaan pembangunan Kabupaten/Kota. Rencana pembangunan tersebut meliputi Rencana Pembangunan Jangka Menengah Desa (RPJMDes) - (RPJMG - Pemerintahan Aceh) untuk jangka waktu 6 (enam) tahun dan Rencana Pembangunan Tahunan Desa atau yang disebut Rencana Kerja Pemerintah Desa (RKPDes) - (RKPG - Pemerintahan Aceh) merupakan penjabaran dari Rencana Pembangunan jangka Menengah Desa untuk jangka waktu 1 (satu) tahun.

Di sejumlah daerah kabupaten/kota, sebutan untuk ADD menggunakan istilah yang berbeda. Hal ini dimungkinkan, mengingat keanekaragaman bahasa dan adat istiadat di Indonesia. Di Aceh sendiri ADD disebut sebagai ADG (Alokasi Dana Gampong) disesuaikan dengan penggunaan nama Gampong untuk menggantikan Desa. ADG merupakan hak Gampong sebagaimana pemerintah daerah kabupaten/kota memiliki hak untuk memperoleh anggaran DAU (Dana Alokasi Umum) dan DAK (Dana Alokasi Khusus) dari Pemerintah Pusat. Tujuan adanya ADG adalah untuk memperkuat kemampuan keuangan Gampong (APBG), dengan demikian sumber APBG terdiri dari PADes - PAG (Pendapatan Alsi Gampong) ditambah ADG, untuk memberi keleluasaan bagi gampong dalam mengelola persoalan pemerintahan, pembangunan serta sosial kemasyarakatan gampong, untuk mendorong terciptanya demokrasi gampong, untuk meningkatkan pendapatan dan pemerataannya dalam rangka mencapai kesejahteraan masyarkat gampong.

\section{Pengelolaan Alokasi Dana Gampong (ADG)}

Pengelolaan Keuangan Alokasi Dana Gampong (ADG) merupakan bagian yangtidak terpisahkan dari Pengelolaan Keuangan Gampong dalam APBG, oleh karenaitu dalam Pengelolaan Keuangan Alokasi Dana Gampong (ADG) harus memenuhiPrinsip Pengelolaan Alokasi Dana Gampong sebagai berikut:

1. Seluruh kegiatan yang didanai oleh Alokasi Dana Gampong (ADG)direncanakan, dilaksanakan dan dievaluasi secara terbuka dengan prinsipdari, oleh dan untuk masyarakat.

2. Seluruh kegiatan harus dapat dipertanggungjawabkan secaraadministrative, teknis dan hukum.

3. Alokasi Dana Gampong (ADG) dilaksanakan dengan menggunakan prinsiphemat, terarah dan terkendali.

4. Jenis kegiatan yang akan dibiayai melalui Alokasi Dana Gampong (ADG)sengat terbuka untuk meningkatkan sarana Pelayanan Masyarakat berupaPemenuhan Kebutuhan Dasar, Penguatan Kelembagaan Desa dan kegiatanlainnya yang dibutuhkan Masyarakat Gampong yang diputuskan melalui Musyawarah Gampong.

5. Alokasi Dana Gampong (ADG) harus dicatat dalam Anggaran Pendapatan danBelanja Gampong (APBG) dan proses penganggarannya mengikuti mekanisme yang berlaku.

\section{Gampong (Desa)}

Gampong (desa) secara administratif merupakan bentuk pemerintahan terkecil yang dipimpin oleh Geuchik (Kepala Desa) dari sebuah pemilihan secara langsung. Secara formal pemerintah telah menerbitkan UU No. 6 Tahun 2014 tentang Desa sebagai dasar hukum yang mengatur segala sesuatu yang dianggap urgen bagi Desa. Desa adalah desa dan desa adat atau yang disebut dengan nama lain, selanjutnya disebut Desa, adalah kesatuan masyarakat hukum yang memiliki batas wilayah yang berwenang untuk mengatur dan mengurus urusan pemerintahan, kepentingan masyarakat setempat berdasarkan prakarsa masyarakat, hak asal usul, dan/atau hak tradisional yang diakui dan dihormati dalam sistem pemerintahan Negara Kesatuan Republik Indonesia (UU No. 6 Tahun 2014).

Keberadaan gampong (desa) telah dikenal lama dalam tatanan pemerintahan di Indonesia jauh sebelum Indonesia merdeka.Masyarakat di Indonesia secara turun temurun hidup dalam suatu kelompok masyarakat yang disebut dengan desa. Desasecara etimologi berasal dari bahasa Sansekerta, desayang berarti tanah air, tanah asal atau tanah kelahiran.Dari perspektif geografis, desa 
atau villagediartikan sebagai 'a group of houses and shops in a country area, smaller than a town'.Desa atau gampong, menurut definisi universal adalah sebuah aglomerasi permukiman di area perdesaan ( rural).Di Indonesia stilah desa adalah pembagian wilayah administratif di Indonesia di bawah Kecamatan, yang dipimpin oleh Kepala Desa, sedangkan di Aceh Barat, Provinsi Aceh,disebut Keuchik Gampong.

Gampong sebagai organisasi pemerintah terendah merupakan tumpuan segenap pelaksana urusan pemerintahan dan pembangunan, Dengan berbagai potensi sumber daya yang dimilikinya. Keberadaan dan kehidupan gampong sebagai suatu kesatuan masyarakat dimana bertempat tinggal sejumlah penduduk yang berhak mengatur rumah tangganya sendiri adalah suatu organisasi masyarakat yang ada sejak lama mendahului terbentuknya Negara Indonesia. Undang-Undang Republik Indonesia Nomor 6 Tahun 2014 Tentang Desa menjelaskan Desa dan Desa adat atau yang disebut dengan nama lain, selanjutnya disebut Desa, adalah kesatuan masyarakat hukum yang memiliki batas-batas wilayah yang berwenang untuk mengatur dan mengurus urusan pemerintahan, kepentingan masyarakat setempat berdasarkan prakasa masyarakat, hak asal usul, dan /atau hak tradisional yang di akui dan dihormati dalam sistem Pemerintahan Negara Kesatuan Republik Indonesia. Selanjutnya di Desa terdapat Pemerintahan Desa yaitu penyelenggaraan urusan pemerintahan dan kepentingan masyarakat setempat dalam sistem pemerintahan Negara Kesatuan Republik Indonesia.

Menurut Undang-Undang Republik Indonesia No 11 Tahun 2006 tentang Pemerintahan Aceh (UUPA) menyebutkan gampong atau nama lain adalah kesatuan masyarakat hukum yang berada di bawah mukim dan dipimpin oleh keucik atau nama lain yang berhak menyelenggarakan urusan rumah tangga sendiri.

\section{Pembangunan Gampong}

Pembangunan gampong merupakan seluruh kegiatan pembangunan yang berlangsung di gampong, meliputi seluruh aspek kehidupan dari seluruh masyarakat yang dilaksanakan secara terpadu dengan mengembangkan swadaya gotong royong. Indikator keberhasilan pembanguna gampong pada dasarnya adalah perbaikan rill dalam kondisi kehidupan masyarakat secara keseluruhan, karena pembangunan senantiasa merupakan proses perbaikan dari suatu keadaan ke keadaan yang lebih baik.

\section{METODE PENELITIAN}

Pendekatan yang digunakan dalam penelitian ini adalah metode penelitian deskripitif dengan pendekatan kualitatif. Metode deskriptif memusatkan perhatian terhadap masalah-masalah atau fenomena yang ada pada saat penelitian dilakukan atau masalah yang bersifat aktual, kemudian menggambarkan fakta-fakta tentang masalah yang diselidiki sebagaimana adanya diiringi dengan interpretasi rasional yang akurat.

Penelitian ini dilakukan di Gampong Pante Ceureumen, Kecamatan Pante Ceureumen Kabupaten Aceh Barat. Penentuan informan untuk proses wawancara dilakukan dengan menggunakan teknik sampling purposive dan teknik snowball sampling. Informan terdiri dari Geuchik, Sekretaris Gampong, Tuha Peut Gampong (Badan Permusyawaratan Desa), pengurus PKK dan tokoh masyarakat.

\section{HASIL PENELITIAN DAN PEMBAHASAN}

\section{Tahapan Dalam Perencanaan Alokasi Dana Gampong (ADG) di Gampong Pante Ceureumen}

Sebagaimana amanat Undang - Undang Nomor 6 Tahun 2014 tentang Desa secara tegas memberikan kewenangan kepada kabupaten dan desa (gampong) dalam mengatur dan mengurus rumah tangganya sendiri. Untuk itu diperlukan sistem pengelolaan keuangan daerah secara baik, benar, transparan dan akuntable. Berdasarkan hal tersebut, kabupaten memiliki kewenangan untuk mengurus kebijakan - kebijakan tentang gampong, terutama dalam hal memberikan pelayanan, peningkatan peran serta masyarakat dan keswadayaan, prakarsa, inovasi dan pemberdayaan masyarakat gampong guna mewujudkan kesejahteraan masyarakat.

Berkaitan dengan hal tersebut, untuk meningkatkan kapasitas Pemerintah Gampong, pembangunan dan pemberdayaan masyarakat gampong perlu mendapatkan perhatian yang lebih 
besar, diataranya melalui pola pengalokasian pengelolaan dana gampong atau Alokasi Dana Gampong (ADG). ADG tersebut dibagikan kepada seluruh gampong dalam Kabupaten Aceh Barat secara adil dan proposional dan penggunaannya sesuai dengan kebutuhan gampong.

ADG diberikan kepada gampong dengan tujuan untuk: (a) meningkatkan penyelenggaraan pemerintahan gampong dalam melaksanakan pelayanan pemerintahan, pembangunan dan kemasyarakatan sesuai dengan kewenangan. (b) meningkatkan kemampuan Lembaga Kemasyarakatan di gampong dalam perencanaan pelaksanaan dan pengendalian pembangunan secara partisipatif sesuai dengan potensi sesebuah gampong, (c) meningkatkan pemerataan pendapatan kesempatan bekerja dan kesempatan berusaha bagi masyarakat gampong. Dan (d) mendorong peningkatan swadaya gotong royong masyarakat.

Sebagai langkah awal, gampong harus terlebih dahulu merencanakan penggunaan APBG (Anggaran Pendapatan Belanja Gampong) di mana ADG masuk ke dalamnya, berdasarkan penggalian kebutuhan dari masyarakat gampong. Hal ini tentu saja berbeda dengan masa lalu, di mana program untuk gampong direncanakan dan ditetapkan dari atas (oleh dinas / instansi pemerintah kabupaten/kota terkait), bukan berasal dari kebutuhan yang sebenarnya digampong. Sehingga, meskipun programnya baik tetapi sering tidak sesuai dengan apa yang dibutuhkan oleh gampong.

UU No. 06 Tahun 2014 pasal 79, mengamanatkan setiap harus menyusun perencanaan pembangunan desa sesuai dengan kewenangannya dengan mengacu pada perencanaan pembangunan Kabupaten/Kota. Rencana pembangunan tersebut meliputi Rencana Pembangunan Jangka Menengah Desa (RPJMDes) - (RPJMG - Pemerintahan Aceh) untuk jangka waktu 6 (enam) tahun dan Rencana Pembangunan Tahunan Desa atau yang disebut Rencana Kerja Pemerintah Desa (RKPDes) - (RKPG - Pemerintahan Aceh) merupakan penjabaran dari Rencana Pembangunan jangka Menengah Desa untuk jangka waktu 1 (satu) tahun. Secara umum, tahapan yang biasa dilakukan dalam proses peruntukkan ADG seharusnya dimusyawarahkan antara Pemerintah Gampong dengan masyarakat gampong serta pihak lainnya (Tuha Peut Gampong, Lembaga Kemasyarakatan, LSM, dll) untuk kemudian dituangkan dalam Peraturan Gampong tentang Anggaran Pendapatan dan Belanja Gampong (APBG) tahun yang bersangkutan.

(1) Tahapan perencanaan pembangunan gampong;

a. Tujuan musyawarah perencanaan gampong

b. Keluaran / hasil

c. Tahapan pasca pelaksanaan

(2) Tahapan pembahasan anggaran gampong

a. Mengkonsultasikan RAPBG (Rencana Anggaran Pendapatan dan Belanja Gampong ) ke masyarakat melalui lembaga Tuha Peut

b. Menyusun tanggapan, koreksi dan usulan perbaikan

c. Perumusan dan penetapan persetujuan

d. Penetapan pengesahan dan pengundangan (menjadi peraturan gampong mengenai APBG) Supaya ADG dapat dimanfaatkan secara nyata berpihak ke masyarakat gampong, minimal $70 \%$ dari ADG harus digunakan untuk pelaksanaan pembangunan baik fisik, ekonomi, dan sosial budaya. Sisanya untuk belanja rutin/operasional. Khusus untuk besaran penghasilan tetap setiap bulan bagi Kepala Desa (Geuchik) dan aparatur gampong ditetapkan minimal setara dengan upah minimum regional Kabupaten/Kota yang dialokasikan di dalam APBK kabupaten/Kota di luar ADG untuk setiap gampong, sedangkan tunjangan lainnya dibebakan pada APBG yang bersumber dari ADD.

(3) Pengawasan ADG

Pengawasan adalah kegiatan mengumpulkan informasi tentang perkembangan atau pelaksanaan sebuah kegiatan. Pengawasan biasanya dilakukan secara berkala selama proses berlangsungnya kegiatan terkait. Sedangkan evaluasi adalah kegiatan menilai secara keseluruhan apakah sebuah kegiatan telah dilaksanakan sesuai dengan rencana atau kegiatan yang telah disusun sebelumnya. Evaluasi biasanya dilakukan pada akhir suatu kegiatan Secara umum, pelaksanaan ADG diawasi oleh tim Pembina di tingkat kabupaten/kota dan kecamatan

Pemerintah gampong terdiri atas kepala desa (geuchik) dan perangkat desa. Perangkat desa terdiri dari secretariat desa, pelaksana kewilayahan; dan pelaksana teknis (UU No 04 Tahun 2014). Peranan pemerintah gampong dalam menyusun dan melaksanakan APBG adalah pelaksanaan dari tugas, fungsi, kewenangan, hak dan kewajiban yang dimiliki pemerintah gampong dalam hal 
pelaksanaan pembangunan di gampong, khususnya yang berkaitan dengan penyusunan dan pelaksanaan APBG.

\section{Tugas dan Peran Pengelola Alokasi Dana Gampong di Gampong Pante Ceureumen}

Untuk mengoptimalkan pelaksanaan ADG di Kabupaten Aceh Barat padatahun anggaran 2015, maka pengelola ADG mempunyai tugas dan peran sesuai dengan Tingkatannya, sSecara umum pengelola ADG di gampong terdiri dari ; (1) Kepala Desa (Geuchik), (2) Badan Permusyarawatan Desa (BPD) - Tuha Peut gampong, (3) Sekretaris gampong (4) Bendahara gampong, dan (5) Lembaga Kemasyarakatan Desa (LPM / Pokmas / PKK / Karang Taruna / OMS).

Selanjutnya menurut salah satu anggota Tuha Peut gampong yaitu Bpk. B bahwa berhubungandengan Alokasi Dana Gampong di Pante Ceureumen, mereka memiliki tugas sebagai berikut;

1) Melaksanakan musyawarah pembahasan RAPBG bersama dengan Keuchik dan Perangkat gampong untuk ditetapkan menjadi APBG.

2) Membahas dan menyetujui Peraturan Gampong (Pergam), Keputusan Keuchik berkaitandengan pelaksanaan kegiatan.

3) Meneliti dan menyetujui Rencana Penggunaan Dana (RPD).

4) Memberi persetujuan kepada Keuchik dalam penunjukan Pelaksana Kegiatan.

5) Mengawasi proses setiap tahapan ADG, mulai dari sosialisasi, perencanaan,pelaksanaan dan pemeliharaan hasil kegiatan tingkat desa

Sekretaris gampong berperan sebagai koordinator pengelolaan keuangan ADG, mempunyai tugas dan tanggung jawabatas keberhasilan pelaksana. Lembaga Kemasyarakatan berfungsi dan berperan sebagai berikut

1) Membantu Pemerintahan gampong dalam proses perencanaan, menggerakkan swadaya dan gotong royong masyarakat untuk melaksanakan program ADG yang berupa infrastruktur gampong yang dilaksanakan secara swadaya, dan pelaksanaan ADG bersifat padat karya.

2) Malaksanakan kegiatan sesuai dengan rencana kerja yang telah ditetapkan.

3) Malaksanakan pengendalian penggunaan ADG dalam berbagai bidang.

\section{Tinjauan Pelaksanaan Perencanaan Anggaran (Penyusunan Alokasi Dana Gampong)}

Gampong Pante Ceureumen menyelenggarakan musyawarah rencana pembangunan gampong (Musrenbang gam) pada tahun 2014 lalu, yang dihadiri oleh kepala dusun, organisasi masyarakat, Tuha Peut (BPD), palmas, tokoh masyarakat, tokoh pemuda, PKK dan tokoh adat. Masyarakat yang diundang cukup antusias dalam mengikuti proses perencanaan pembangunan, mereka merasa lebih dihargai sebagai anggota masyarakat, karena diikutsertakan dalam proses perencanaan pembangunan. Masyarakat memang sangat mengharapkan dilibatkan dalam proses perencanaan pembangunan, namun karena kurangnya sosialisasi tentang perencanaan pembangunan menyebabkan mereka tidak hadir dalam preses musrenbang tersebut.

Pemerintah gampong Pante Ceureumen terus berusaha untuk dapat melibatkan masyarakat dalam setiap tahap proses perencanaan pembangunan setiap tahunnya. Keuchik menjelaskan bahwa proses perencanaan pembangunan yang diselenggarakan selama sehari penuh itu sedapat mungkin bisa melibatkan masyarakat secara keseluruhan, namun karena kesibukan dan keterbatasan ruang maka tidak seluruhnya diundang, namun aspirasi mereka sudah ditampung dalam list daftar prioritas kegiatan pembangunan.

Pasca musrenbang gampong, sebagaimana yang telah diatur bahwa rancangan rencana pembangunan gampong akan dimasukkan ke dalam Rencana Anggaran Pembangunan dan Belanja Gampong (RAPBG), di mana anggaran ADG akan masuk di dalamnya sebagai salah satu sumber APBG. Dengan demikian Alokasi Dana Gampong adalah hasil dari perencanaan musrenbang.

Peran masyarakat dapat terlihat dalam hal partisipasinya dalam penyusunan ADG yang melalui proses musyawarah pembangunan gampong, kemudian penyusunan APBG. Keterlibatan tokoh masyarakat sangat penting untuk mendapatkan hasil rencana pembangunan yang tepat sasaran. Kemampuan sumber daya manunia yang ikut berpartisipasi dalam perencanaan pembangunan menjadikan Alokasi Dana Gampong (ADG) yang partisipatif dan tepat guna.

Anggaran Pendapatan dan Belanja Gampong (APBG) adalah peraturan gampong yang memuat sumber-sumber penerimaan dan alokasi pengeluaran gampong dalam kurun waktu satu 
tahun. APBG terdiri atas bagian pendapatan gampong, belanja gampong, dan pembiayaan. Rancangan APBG dibahas dalam musyawarah perencanaan pembangunan gampong (musrenbang gampong). Keuchik bersama Tuha Peut menetapkan APBG setiap tahun dengan Qanun Gampong. Perencanaan pembangunan gampong disusun secara partisipatif oleh pemerintah gampong sesuai dengan kewenangannya. Dalam menyusun perencanaan pembangunan gampong wajib melibatkan lembaga kemasyarakatan gampong.

Saat ini hampir seluruh kegiatan pembangunan di gampong, pelaksanaannya dilakukan dengan metoda pembangunan partisipatif, namun masing-masing kegiatan pembangunan terdapat perbedaan pada target sasaran masyarakat yang direncanakan untuk berperan serta dalam kegiatan perencanaan sampai dengan pelaksanaan pembangunan. Perbedaan itu terletak pada tingkatan kedudukan fungsi dan peran para pemangku kepentingan dalam masyarakat. Misalnya dalam program pemberdayaan masyarakat, di mana masyarakat yang diikutsertakan untuk berperan serta dalam kegiatan perencanaan hingga dengan pelaksanaan pembangunan hanya para pelaku yang mempunyai kedudukan penting saja misalnya tokoh masyarakat, aparatur gampong. Dalam program pemberdayaan perempuan yang diikutsertakan untuk berperan aktif dalam perencanaan serta dalam pelaksanaan adalah tokoh-tokoh perempuan. Berbeda halnya dengan yang dilakukan pada program penanggulangan kemiskinan masyarakat, di mana setiap tahapan kegiatan dari perencanaan sampai dengan pelaksanaan harus melibatkan warga masyarakat secara keseluruhan tanpa memandang usia, jenis kelamin, kedudukan dalam masyarakat dan jenjang pendidikan.

\section{Persyaratan Pencairan Alokasi Dana Gampong}

ADG dilaksanakan oleh Pemerintah Gampong, Pengelola ADG di gampong dan pihak terkait lain di kecamatan dan kabupaten terlebih dahulu melakukan persiapan dan melengkapi persyaratan yang diperlukan untuk keperluan pencairan dana.

Adapun Alokasi Dana Gampong untuk GampongPante Ceureumen Tahun 2015 berjumlah Rp. 200.000.000,00 (Dua Ratus Juta Rupiah). Penggunaan dana Alokasi Dana Gampong yang diperuntukkan bagi kegiatan pembangunan dan pemberdayaan. Dimana $30 \%$ untuk operasional Keuchik, Aparatur gampong, PKK, Karang Taruna, 70\% lagi digunakan untuk pemberdayaan masyarakat untuk penunjang kegiatan kelembagaan, bimbingan teknis Keuchik dan aparaturnya, bintek Tuha Peut gampong (BPD), penunjang pokja profil desa, pembuatan drainase, belanja komputer,belanja pengadaan linmas, belanja HUT Gampong, HUT RI.

Untuk preses pencairan dana tersebut, masing-masing kegiatan tersebut dengan melampirkan:

1) Surat Permohonan kepada Keuchik Gampong.

2) Rencana Kegiatan dan Rencana Anggaran Biaya (RAB).

3) Surat sebagai mana dimaksud di atas ditandatangani oleh Ketua Pelaksana Kegiatan yang bersangkutan.

Alur proses pencairan dana Alokasi Dana Gampong (ADG):

a. Pengajuan dana oleh tim pelaksana kegiatan sesuai dengan kebutuhan dana dilapangan.

b. Setelah permohonan disetujui oleh Keuchik, Bendahara Gampong mencairkan/menyerahkan dana kegiatan kepada tim pelaksana kegiatan.

c. Tim Pelaksanan kegiatan berkewajiban mempertanggungjawabkan Penggunaan Danabaik secara fisik maupun administrasi dengan membuat dan menyampaikan SPJkepada Keuchik yang selanjutnya SPJ tersebut digunakan oleh Bendahara Gampong untuk membuat laporan pertanggungjawaban

d. Pengajuan danaADG selanjutnya setelah SPJ sebelumnya disampaikan.

\section{SIMPULAN DAN SARAN}

\section{A. Simpulan}

Menurut Undang-Undang No 06 Tahun 2014 tentang Desa, menjelaskan Desa adalah desa dan desa adat atau yang disebut dengan nama lain, selanjutnya disebut Desa, adalah kesatuan masyarakat hukum yang memiliki batas wilayah yang berwenang untuk mengatur dan mengurus urusan pemerintahan, kepentingan masyarakat setempat berdasarkan prakarsa masyarakat, hak asal usul, dan/atau hak tradisional yang diakui dan dihormati dalam sistem pemerintahan Negara Kesatuan Republik Indonesia. Pemerintahan desa adalah penyelenggaraan urusan pemerintahan dan 
kepentingan masyarakat setempat dalam sistem pemerintahan Negara Kesatuan Republik Indonesi. Selanjutnya pemerintah Desa adalah Kepala Desa atau yang disebut dengan nama lain dibantu perangkat Desa sebagai unsur penyelenggara Pemerintahan Desa. Menurut Undang-Undang Republik Indonesia No 11 Tahun 2006 tentang Pemerintahan Aceh (UUPA) menyebutkan gampong atau nama lain adalah kesatuan masyarakat hukum yang berada di bawah mukim dan dipimpin oleh keucik atau nama lain yang berhak menyelenggarakan urusan rumah tangga sendiri.

Struktur pemerintah di level bawah ini (Gampong), memegang peranan penting dalam meningkatkan kesejahteraan masyarakat di tingkat paling bawah. Memahami proses pada seluruh tahapan pengelolaan APBG (Anggaran Pendapatan dan Belanja Gampong) berkaitan penyusunan, pelaksanaan, pertanggungjawaban. Proses pengelolaan APBG yang didasarkan pada prinsip partisipatif, transparansi dan akuntabel akan memberikan nilai bahwa pemerintahan gampong dijalankan dengan baik.

Adanya Alokasi Dana Gampong yang memadai untuk menunjang sumber penerimaan APBG, diharapkan akan mampu mendorong roda pemerintahan di tingkat gampong, termasuk untuk menanggapi kebutuhan-kebutuhan yang mampu ditangani di tingkat gampong yang merupakan kewenangan gampong. APBG yang baik dapat mendorong partisipatif warga lebih luas pada prosesproses perencanaan dan penganggaran pembangunan, pelaksanaan dan monitoring dan evaluasi. Namun demikian, agar terwujudnya APBG yang baik perlu dilakukan penguatan Pemerintahan Gampong (Pemerintah Gampong dan Tuha Peut Gampong) dalam mengelola keuangan gampong, khususnya berkaitan dengan penyusunan, pelaksanaan dan pertanggungjawaban APBG, agar APBG atau ADG yang disusun berorientasi kepada peningkatan kesejahetraan masyarakat gampong dan memenuhi prinsip-prinsip good governance seperti transparansi, partisipatif, efektifitas dan akuntabel. Dari temuan penelitian disarankan beberapa hal sebagai berikut:

1. Untuk lebih meningkatkan lagi Partisipasi Masyarakat dalam Pembangunan gampong, diharapkan pemerintah dapat meningkatkan alokasi dana setiap tahunnya. Sehingga dengan keberhasilan pembangunan gampong akan menjadi keberhasilan pembangunan secara menyeluruh di kabupaten. Selain itu perlu penyempurnaan tahapan pelaksanaan perencanaan partisipatif agar dapat dilaksanakan secara simpel dan mudah dipahami baik oleh perangkat pemerintah desa dan kecamatan maupun masyarakat dan tokoh masyarakat dengan tidak mengurangi prinsip-prinsip partisipatif.

2. Pemerintah gampong perlu mengoptimalkan kegiatan identifikasi masalah dan kebutuhan masyarakat mulai tingkat lingkungan bawah supaya gampong mempunyai data tentang potensi, masalah dan kebutuhan masyarakat serta Pemerintah gampong mengoptimalkan pemanfaatan data tersebut agar perencanaan pembangunan dapat mendekati kebutuhan masyarakat.

3. Perlu ada peningkatan pemahaman perangkat gampong/kecamatan, tokoh masyarakat dan masyarakat umumnya mengenai mekanisme perencanaan pembangunan, pentingnya perencanaan pembangunan melalui kegiatan pelatihan atau penambahan wawasan, pendekatan yang aktif melalui kader pembangunan kepada masyarakat sehingga masyarakat dapat berpartisipatif aktif dalam proses perencanaan pembangunan.

4. Kemampuan tokoh masyarakat terutama yang masuk dalam keanggotaan tuha peut perlu ditingkatkan untuk dapat terlibat aktif dalam perencanaan pembangunan gampong yang akan menghasilkan Anggaran Dana Gampong yang mengena saasaran dan bersifat partisipatif

5. Bagi aparat pemerintahan yang masih merasa terbatas dalam memahami kebiajakan ADG, agar terus belajar, bertanya dan mencari informasi-informasi tentang kebijakan ADG serta terus melakukan koordinasi dengan pihak kecamatan maupun pihak kabupaten.

6. Membuat papan pengumuman disetiap dusun untuk mengumumkan laporan pelaksanaan kebijakan ADG agara diketahui oleh seluruh masyarakat.

B. Saran

1. Untuk lebih meningkatkan lagi partisipasi masyarakat dalam pembangunan gampong, diharapkan pemerintah dapat meningkatkan Alokasi Dana setiap tahunnya. Sehingga dengan keberhasilan pembangunan gampongakan menjadi keberhasilan pembangunan secara menyeluruh di kabupaten. 
2. Agar proses pengesahan pertanggung jawaban keuangan kebijakan ADG tidak memakan waktu yang lama, diharapkan pemerintah dapat menetapkan satu pos verifikasi SPJ saja, apakah dikecamatan atau di Bagian Keuangan Sekretariat Daerah.

3. Bagi aparat pemerintahan yang masih merasa terbatas dalam memahami kebiajakan ADG, agar terus belajar, bertanya dan mencari informasi-informasi tentang kebijakan ADG serta terus melakukan koordinasi dengan pihak kecamatan maupun pihak kabupaten.

4. Membuat papan pengumuman disetiap dusun untuk mengumumkan laporanpelaksanaan kebijakan ADG agara diketahui oleh seluruh masyarakat.

\section{REFERENSI}

Edward III, George C (edited). 1984. Public Policy Implementing. London: Jai Press Inc.

Grindle, Merilee S., (ed). 1980. Politics and Apolicy Implementation in the Third World, New Jersey: Princetown University Press.

Islamy, Irfan. 2007. Prinsip-Prinsip Perumusan Kebijaksanaan Negara. Jakarta: Bumi Aksara

Islamy, Irfan. 1997. Prinsip-prinsip Perumusan Kebijaksanaan Negara. Jakarta: Bumi Aksara.

Martoyo, Susilo. 2007. Manajemen Sumber Daya Manusia, Edisi 5, Cetakan Pertama, Yogyakarta: BPFE.

Parsons, W. 1995. Public Policy: An introduction to the theory and practice of policy analysis. London: Edward Elgar.

Ripley, Ronald B and Grace Franklin. 1986. Policy Implementation Bereaucracy. Chicago: Dorsey Press.

Setiawan, Guntur. 2004. Implementasi Dalam Birokrasi Pembangunan. Bandung: Remaja Rosdakarya Offset.

Sumaryadi, I Nyoman. 2005. Efektivitas Implementasi Kebijkan Otonomi Daerah. Jakarta: Citra Utama.

Tangkilisan, Hesel Nogi. 2003. Implementasi Kebijakan Publik. Yogyakarta: Lukman Offset YPAPI.

Undang-Undang Republik Indonesia Nomor 06 Tahun 2014 tentang Desa

Undang-Undang Republik Indonesia Nomor 11 Tahun 2006 Tentang Pemerintahan Aceh

Usman, Nurdin. 2007. Konteks Implementasi Berbasis Kurikulum. Yogyakarta: Bintang Pustaka.

Weimer, David.L,.dan Vining, Aidan R. 1999. Policy Analysis: Concepts and Practice, third edition, New Jersey: Prentice Hall, Chapter 13.

Wibawa, Samudera. 1994. Evaluasi Kebijakan Publik. Jakarta: Raja Grafindo Persada. 